\title{
Seismogenic frictional melting in the magmatic column
}

\author{
J. E. Kendrick ${ }^{1,2, *}$, Y. Lavallée ${ }^{1}$, K.-U. Hess ${ }^{2}$, S. De Angelis ${ }^{1}$, A. Ferk ${ }^{2,3}$, H. E. Gaunt ${ }^{4}$, P. G. Meredith ${ }^{4}$, D. \\ B. Dingwell ${ }^{2}$, and R. Leonhardt ${ }^{3}$ \\ ${ }^{1}$ School of Earth, Ocean and Ecological Sciences, University of Liverpool, Liverpool, L69 3GP, UK \\ ${ }^{2}$ Department of Earth and Environmental Sciences, Ludwig-Maximilians-Universität, Theresienstr. 41, \\ 80333 Munich, Germany \\ ${ }^{3}$ Central Institute for Meteorology and Geodynamics, 1190 Vienna, Austria \\ ${ }^{4}$ Rock \& Ice Physics Laboratory, Department of Earth Sciences, University College London, Gower Street, \\ London, UK
}

Correspondence to: J. E. Kendrick (jackie.kendrick@liverpool.ac.uk)

Received: 18 September 2013 - Published in Solid Earth Discuss.: 16 October 2013

Revised: 29 January 2014 - Accepted: 6 February 2014 - Published: 9 April 2014

\begin{abstract}
Lava dome eruptions subjected to high extrusion rates commonly evolve from endogenous to exogenous growth and limits to their structural stability hold catastrophic potential as explosive eruption triggers. In the conduit, strain localisation in magma, accompanied by seismogenic failure, marks the onset of brittle magma ascent dynamics. The rock record of exogenous dome structures preserves vestiges of cataclastic processes and thermal anomalies, key to unravelling subsurface processes. Here, a combined structural, thermal and magnetic investigation of a shear band crosscutting a large block erupted in 2010 at Soufrière Hills volcano (SHV) reveals evidence of faulting and frictional melting within the magmatic column. The mineralogy of this pseudotachylyte vein offers confirmation of complete recrystallisation, altering the structure, porosity and permeability of the material, and the magnetic signature typifies local electric currents in faults. Such melting events may be linked to the step-wise extrusion of magma accompanied by repetitive long-period (LP) drumbeat seismicity at SHV. Frictional melting of Soufrière Hills andesite in a high velocity rotary shear apparatus highlights the small slip distances $(<15 \mathrm{~cm})$ thought to be required to bring $800^{\circ} \mathrm{C}$ magma to melting point at upper conduit stress conditions $(10 \mathrm{MPa})$. We conclude that frictional melting is a common consequence of seismogenic magma fracture during dome building eruptions and that it may govern the ascent of magma in the upper conduit.
\end{abstract}

\section{Background}

Dome-building eruptions hold potential for volcanic catastrophes, with dome collapse leading to devastating pyroclastic flows with almost no warning (Voight and Elsworth, 2000; Carn et al., 2004; Herd et al., 2005). Extrusion of highviscosity magma at arc volcanoes is frequently accompanied by seismic activity in the form of repetitive drumbeat, LP (long period) events (Iverson et al., 2006; Neuberg et al., 2006; De Angelis, 2009). At Soufrière Hills volcano (SHV) this seismicity has been attributed to magma fracture (De Angelis and Henton, 2011) and cyclic plug extrusion (Costa et al., 2012), which is dictated by magma supply rate, conduit geometry (Rowe et al., 2004), overpressure build-up (Edmonds and Herd, 2007; Lensky et al., 2008) and rheological stiffening (Voight et al., 1999). At SHV crystal growth during ascent suppresses the thermal runaway due to viscous heating and so the magma temperature remains close to that of the magma chamber (Hale et al., 2007), which has been estimated at $830-858^{\circ} \mathrm{C}$ (Melnik and Sparks, 2002; Devine et al., 1998; Murphy et al., 2000) up to $880^{\circ} \mathrm{C}$ when heated by an incoming mafic intrusion (Devine et al., 1998; Barclay et al., 1998). At these temperatures heterogeneity develops in crystalline magmas in the upper conduit; areas of dense magma are surrounded by shear zones at the conduit margin (Kendrick et al., 2013; Kendrick et al., 2012; Hale and Wadge, 2008; Lavallée et al., 2013), controlling the development of the degassing network (Carn et al., 2004; Watts et al., 2002; Plail et al., 2014; Laumonier et al., 2011). 


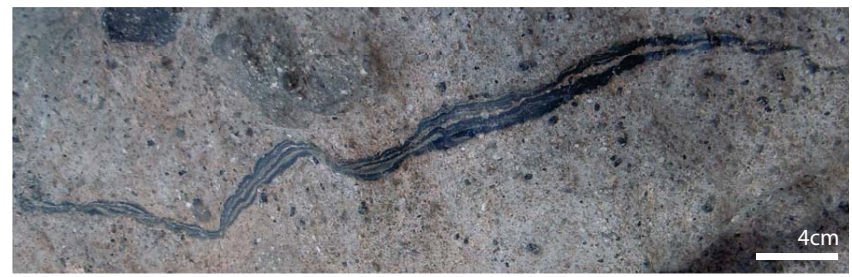

Fig. 1. Field photo of the shear band. In the shear band up to seven interlayered bands of aphanitic pseudotachylyte and cataclasite layers and lenses are observed. The photograph illustrates the lateral variation in thickness and its morphology, which suggests formation in viscous magma in the conduit.

Beyond this point brittle fracture and sliding can lead to formation of gouge, cataclasite (Kennedy et al., 2009; Cashman et al., 2008; Kennedy and Russell, 2012) and pseudotachylyte (Kendrick et al., 2012) akin to tectonic fault zones (Lin, 1996; Curewitz and Karson, 1999; Kirkpatrick and Rowe, 2013; Sibson, 1975). This may be linked to repetitive seismicity at SHV (Neuberg et al., 2006), hence, the fracture and slip properties of ascending magma (e.g. Lavallée et al., 2008; Tuffen and Dingwell, 2005; Kendrick et al., 2013; Cordonnier et al., 2012; De Angelis and Henton, 2011) are of critical importance to understanding the frequent transitions from effusive to explosive behaviour during volcanic eruptions (Okumura et al., 2010; Castro et al., 2012; Lavallée et al., 2013).

\section{Analysis and interpretation}

\subsection{Sample Description}

Metre-scale blocks from block-and-ash flow deposits at SHV present the opportunity to study textural and structural information from conduit and dome material that would otherwise remain inaccessible due to the current volcanic unrest. Of specific interest is a $\sim 2 \mathrm{~m}$ long shear band located in an andesitic block erupted in 2010 due to its vitreous appearance, lateral extent and structural signature. The shear band cross-cuts the centre of its metre-scale host rock, which confirms its origin within the magmatic column and contrasts to frictional marks on the surface of blocks formed during turbulent flow of pyroclastics at SHV (Grunewald et al., 2000). A multi-parametric approach is employed to assess its structural, mineralogical, kinetic and magnetic character (see detailed methodology in the Appendix).

\subsection{Petrography}

The shear band consists of interlayered aphanitic (interpreted herein as) pseudotachylyte and granular cataclasite up to $3 \mathrm{~cm}$ thick which pinches out, widens and bends along length $(\sim 2 \mathrm{~m})$ and breadth (Figs. 1,2$)$. The shear band was distinguished from an injection vein by these features, in con-

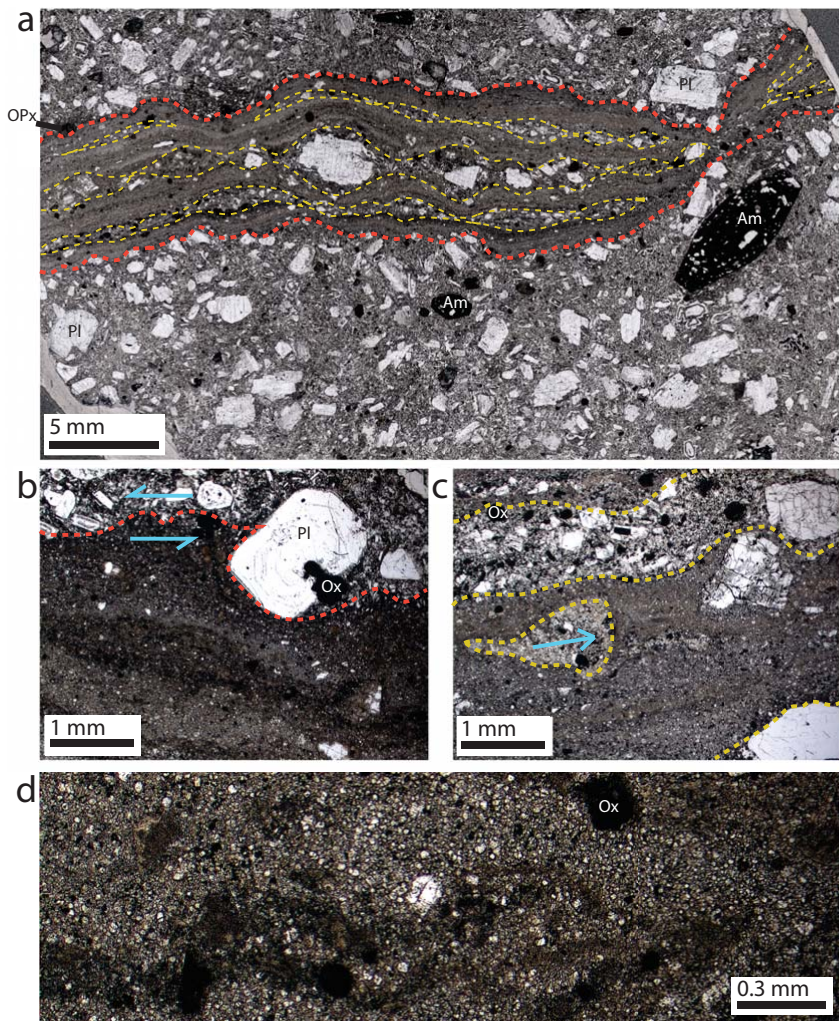

Fig. 2. Photomicrographs of the shear band. (a), a wide view of pseudotachylyte (dark grey) and cataclasite (grey) layers in the shear band cutting through the andesite host rock, containing plagioclase $(\mathrm{Pl})$, amphibole pseudomorphs (Am, replaced by reaction products), pyroxene (here OPx) and FeTi oxides (Ox). Morphology of the vein shows the shear band pinching out and lenses of cataclasites between pseudotachylyte veins of more constant thickness, which show flow textures. (b), inferred shear direction from flow morphology of the pseudotachylyte around a host-rock phenocryst at the vein boundary. (c), cataclastic lens hosted in a pseudotachylyte layer with bulbous onset and elongate tail indicating flow direction of the band. (d), internal structure in the pseudotachylytecataclasite interface indicating turbulent flow. Red dashed lines mark the boundary of the shear band, yellow dashed lines show boundaries between pseudotachylyte and cataclasites, arrows represent inferred flow/shear directions.

trast to the centimetre-scale half-bell morphology (tapering rapidly from the vein base and less rapidly toward the tip) envisaged for pseudotachylyte injection veins (Griffith et al., 2012). The morphology also demonstrates post-formation ductile deformation in the still-flowing, conduit-dwelling, magma. The interlayered pseudotachylyte and cataclasite indicate repeat slip events along the fault surface as is frequently observed in tectonic fault zones (e.g. Kirkpatrick and Rowe, 2013; Rowe et al., 2005; Kim et al., 2010; Sibson, 1977; Swanson, 1992). Intermittently along the length of the shear band up to seven layers can be identified (Figs. 1, 2), and this can be envisaged in the 3-D reconstruction of the vein and pore space in Fig. 3. Permeability was measured 


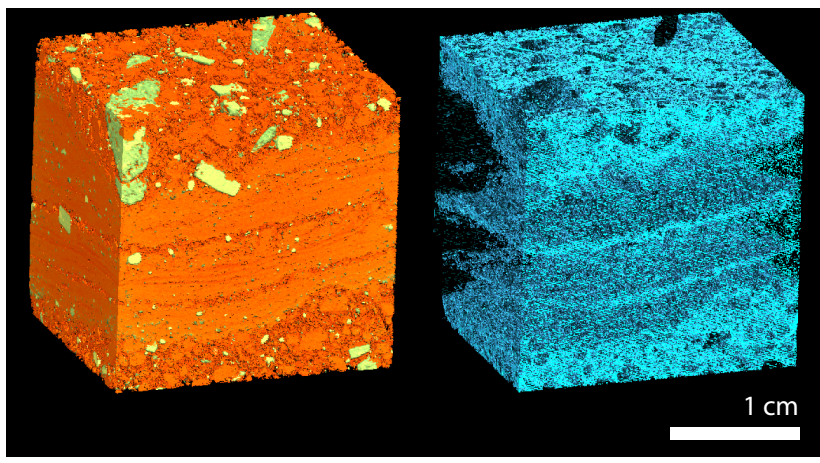

Fig. 3. Tomography of the shear band in the host rock. Solid fraction of the sample is shown in yellow (oxides, amphibole and pyroxenes) and orange (plagioclase and groundmass). A 3-D reconstruction of the pore space is shown in blue, highlighting the negligible porosity of the pseudotachylyte layers. Pores were selected as areas with grey level of 0 (black only), hence the figure may under-represent the porous fraction. Images have a pixel/voxel size of $20.0 \mu \mathrm{m}, 1000$ images for $360^{\circ}$ (average of 3 single images, one image skipped), with exposure time of $1 \mathrm{~s}$.

on the host rock, and both parallel and perpendicular to the shear band on 34-40 (length) by $25 \mathrm{~mm}$ cylindrical samples at 5-10 MPa pressure intervals from 5-50 MPa (for more information on methodology see Heap et al., 2014). Results indicate that at low pressures the shear band may be up to three orders of magnitude less permeable than the host rock, although this contrast diminishes at higher pressure (Fig. 4).

The host rock, a porphyritic andesite with $23 \%$ porosity (determined via helium pycnometry), has a crystal assemblage (total crystallinity $<60 \%$ ) of plagioclase, amphibole and orthopyroxene phenocrysts, with some quartz grains and FeTi oxide (Ti-magnetite to ilmenite) set in a groundmass of orthopyroxene and plagioclase with trace amounts of zircon, apatite and chlorite (Fig. 6). There are two types of plagioclase, categorised as having $<$ An80 (type 1) or $>$ An80 (type 2). Type 1 is more common and is present across the sample whereas type 2 tends to form as rims and is only present in the host rock and cataclasite bands more than $\sim 1 \mathrm{~mm}$ thick (Fig. 6). Amphiboles are broken down into pseudomorphs containing plagioclase, pyroxene, opacite and abundant FeTi oxides, as has been reported from earlier in the eruption (Zellmer et al., 2003). Phenocrysts are for the most part euhedral and have few fractures, and there is no apparent orientation or foliation in phenocrysts or groundmass. What interstitial glass may have existed is fully devitrified; the glass has been replaced by silica residue, including feldspar and cristobalite.

In contrast to the host rock groundmass (Fig. 5a) the pseudotachylyte consists of fine grained $(10-40 \mu \mathrm{m})$, equant and well sorted quartz, plagioclase, FeTi oxides, pyroxene, feldspar, cristobalite and cordierite (Fig. 5b), and occasional larger sieve-textured plagioclase phenocrysts (Fig. 5d) as well as higher levels of chlorite (Fig. 6e). The pseudotachy-

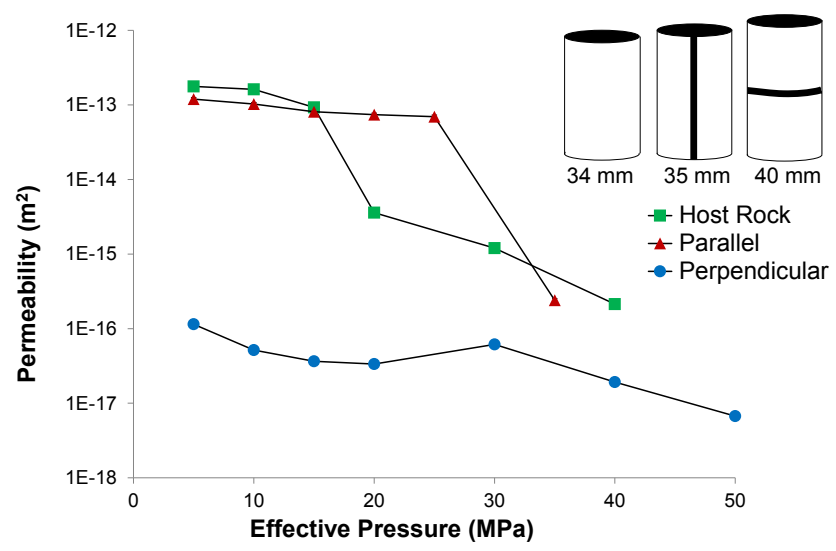

Fig. 4. Shear zone permeability. Steady-state water permeability measured at effective pressures of 5-50 MPa for sample cores ( $2.5 \mathrm{~cm}$ diameter) with no shear band (host rock), and drilled parallel and perpendicular to the pseudotachylyte-bearing shear band (inset). When the pseudotachylyte is parallel to flow, the flow rate is still controlled by the host rock, but when the vein runs perpendicular to flow it controls the permeability, which is reduced. Additionally permeability is reduced as effective pressure is increased and cracks are accordingly closed, this effect is less apparent in the perpendicular-cut sample as the porosity of the pseudotachylyte is already negligible.
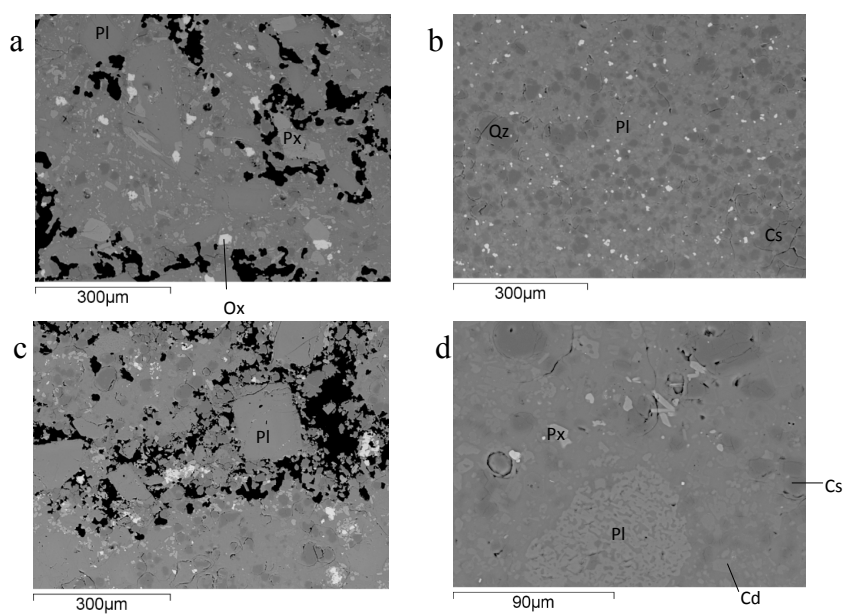

Fig. 5. Backscatter electron (BSE) images of the sample. (a) Host rock, (b) pseudotachylyte, (c) cataclasite and (d) sieve textured plagioclase in the pseudotachylyte. Here Qz is quartz, Pl is plagioclase, $\mathrm{Px}$ is pyroxene, $\mathrm{Ox}$ is FeTi oxide, $\mathrm{Cd}$ is cordierite and Cs is cristobalite.

lyte has a porosity of $1 \%$ (measured by helium pycnometry), has flow textures (Fig. 2b, c) and has sharp but undulating contacts with the host rock. The transitions into the cataclasites are more gradual but are distinguishable by the change in porosity and grain size. The cataclasites appear to be granular aggregates of both starting material and pseudotachylyte, with grain sizes up to several millimetres in diameter for occasional phenocrysts, although more typically $20-400 \mu \mathrm{m}$ 
(Figs. 5, 6). Porosity is localised in patches and averages $15 \%$ (by helium pycnometry) while grains are equant but angular and are often fragments. The mineral assemblage is made up of plagioclase, quartz, altered amphibole (which appears in bands $>1 \mathrm{~mm}$ thick), FeTi oxides (which appear as granular clusters) and cristobalite. In earlier stages of the eruption silica polymorphs, including cristobalite, have comprised up to $15 \mathrm{wt} \%$ in the magma, and its presence here was verified using differential scanning calorimetry (Sect. 2.3).

\subsection{Kinetics}

High sensitivity differential scanning calorimetry (HS-DSC) measurements on the host rock groundmass revealed a reversible endothermic peak at $190^{\circ} \mathrm{C}$ at a heating/cooling rate of $10^{\circ} \mathrm{C} \mathrm{s}^{-1}$, which recurred after cooling and reheating, verifying the $\alpha-\beta$ phase transition of cristobalite. While the ideal phase transition occurs at $272{ }^{\circ} \mathrm{C}$, highly distorted crystals originating from a gel or glass can have a lower transition temperature, and inversion temperatures of $120-272{ }^{\circ} \mathrm{C}$ have been recorded (Sosman, 1965). The shear band reveals no such endothermic peak as a result of cristobalite (despite it being visible in thin section (Fig. 5b) in both the pseudotachylyte and cataclasite), however, a repeatable endothermic peak at $572{ }^{\circ} \mathrm{C}$ (Fig. 7) can be attributed to the $\alpha-\beta$ phase transition of quartz (Sosman, 1965). The detection of the phase transitions reflects the relative abundance of the silica polymorphs in the vein versus host rock (Fig. 5).

The melting temperature of the shear zone also differs from the host rock; low sensitivity (LS)-DSC measurements on the groundmass of the host rock show two broad melting peaks between $1050-1250^{\circ} \mathrm{C}$ and $1350-1450^{\circ} \mathrm{C}$ (post optical analysis of samples after runs to 1300 and $1500^{\circ} \mathrm{C}$ indicate partial and complete melting of all phases respectively), whereas the aphanitic pseudotachylyte vein shows a broad melting peak between 1200 and $1400^{\circ} \mathrm{C}$ (post optical analysis indicates complete melting of all phases). This difference arises from the distinct mineralogy (Fig. 6) formed during disparate crystallisation histories.

\subsection{Magnetic anomalies}

Crystallisation in the volcanic pseudotachylyte vein recorded a distinct magnetic signature, as is often noted in tectonic and impact generated pseudotachylytes (Ferré et al., 2005; Freund et al., 2007), which supports its status as a frictionally generated melt. The remanence of the pseudotachylyte is carried by a low coercive material with a Curie temperature of $320^{\circ} \mathrm{C}$, whereas the host rock, which also shows low coercive behaviour, has two Curie temperatures at 400 and $540^{\circ} \mathrm{C}$. Alternating field demagnetisation of different remanent magnetisations was used to identify further differences between the two samples (Fig. 8). The demagnetisation pattern of the natural remanence magnetisation (NRM) of the pseudotachylyte is similar to an isothermal rema-

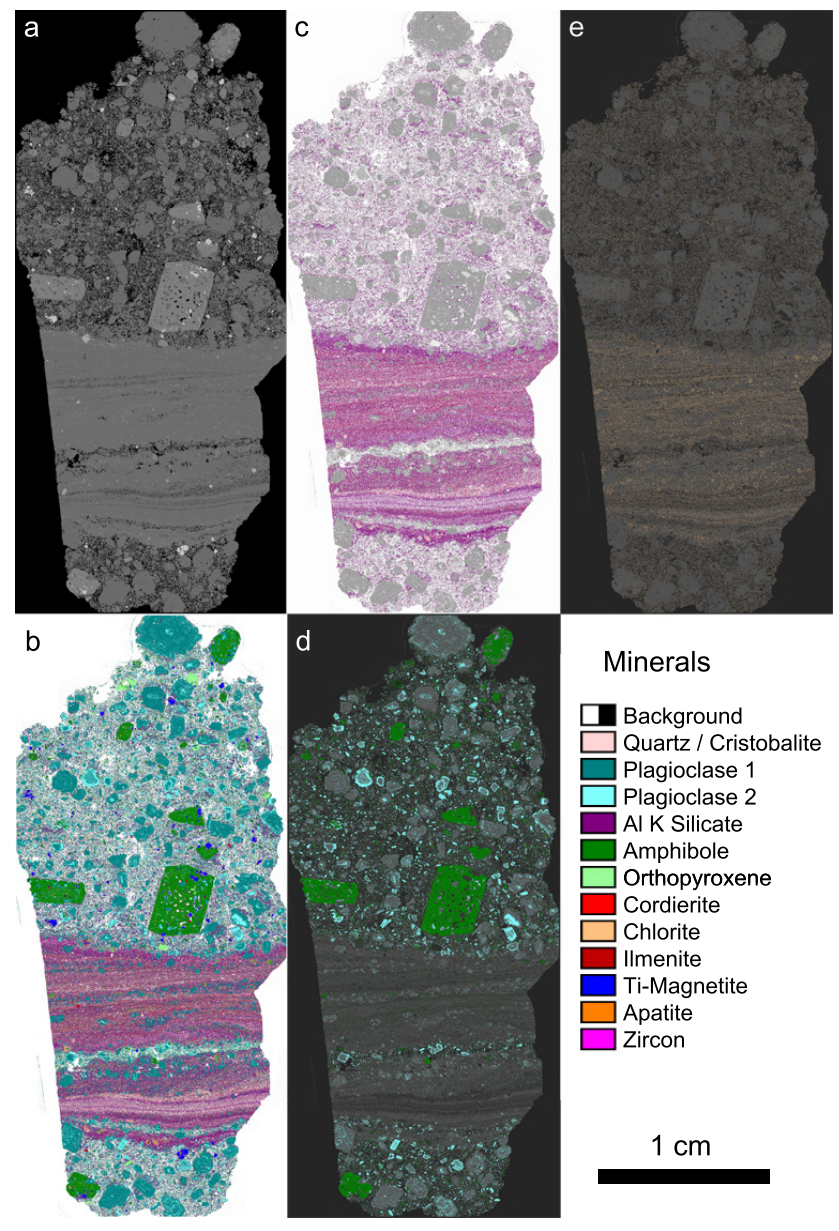

Fig. 6. Distribution of minerals using QEMSCAN (Quantitative Evaluation of Minerals by SCANning electron microscopy). (a) BSE image of the thin section used for analysis, including host rock, cataclasite and pseudotachylyte (b) composite of all resolved minerals and porosity in white (c) distribution of Al K silicate (potentially feldspar) and cordierite with other minerals in greyscale and porosity in white and (d) distribution of plagioclase type 2 and amphibole and (e) distribution of chlorite with other minerals in greyscale and porosity in black.

nent magnetisation (IRM) pattern, whereas the demagnetisation patterns of the host rock display similarities between the NRM and anhysteretic remanent magnetisation (ARM). Thus, the pseudotachylyte has seen a strong magnetic field that overwrote the previous thermoremanent magnetisation of the magma. Due to the in situ proximity of the two samples (within $2 \mathrm{~cm}$ ) this IRM cannot originate from a lightning strike (known to enforce magnetisation). Instead, it demonstrates simultaneous high local electric currents and frictional melt occurring on a fault, known to produce a high IRM (Ferré et al., 2005; Freund et al., 2007; Kendrick et al., 2012). 


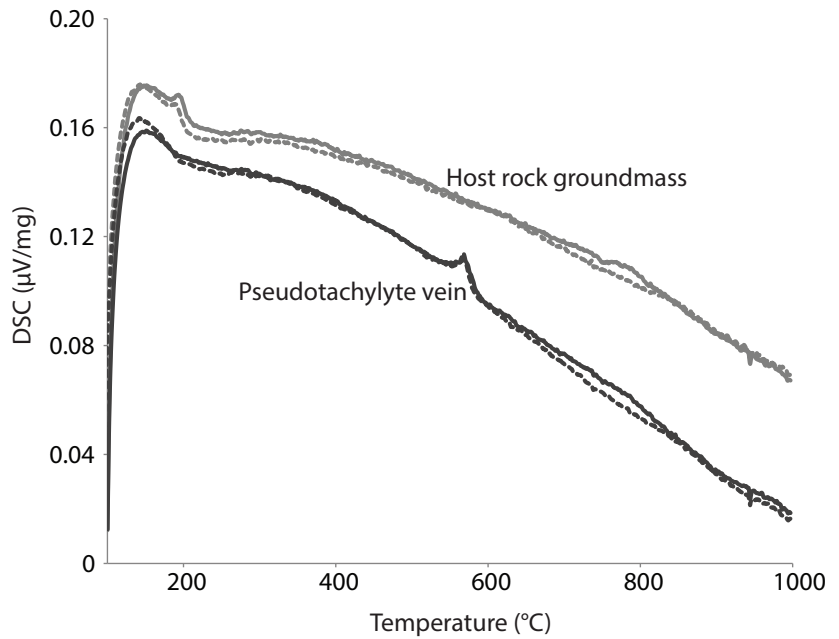

Fig. 7. Thermal measurements by high sensitivity differential scanning calorimetry (HS-DSC). Measurements were carried out using a Netzsch DSC 404 C. A sharp endothermic peak at about $190^{\circ} \mathrm{C}$ in the host rock (light grey trace) corresponds to a cristobalite $\alpha-$ $\beta$ phase transition and the trace shows no evidence of a potential glassy phase. An endothermic peak at about $570^{\circ} \mathrm{C}$ corresponding to the $\alpha-\beta$ phase transition in quartz is seen in the pseudotachylyte vein (dark grey trace). The same exothermic peaks are visible on the second run of the experiments with the same sample (dashed lines), confirming their respective phase transitions.

\section{A model}

Pseudotachylyte has previously been linked to seismogenic ruptures (Magloughlin and Spray, 1992) at slip velocities over $0.1 \mathrm{~m} \mathrm{~s}^{-1}$ (Spray, 2010), and at SHV may be linked to the recorded repetitive drumbeat seismicity (Rowe et al., 2004; Watts et al., 2002; Luckett et al., 2008; Neuberg et al., 1998) inferred to result from magma failure and stickslip events along conduit margins (Neuberg et al., 2006; De Angelis and Henton, 2011; Harrington and Brodsky, 2007). Throughout the eruption LP events occurred at $\sim 50$ s intervals with a P-wave pulse duration of approximately $0.15 \mathrm{~s}$ (Fig. 9), which translates to a source duration of the same time frame (Harrington and Brodsky, 2009). In order to calculate the displacement during these events we average the cumulative source displacement over $24 \mathrm{hr}$, for example, the $235 \mathrm{~m}$ preceding the 29 July 2008 dome collapse (De Angelis, 2009) divided by the 1,588 recorded events (of similar size) during that period to provide a mean slip distance of $15 \mathrm{~cm}$ per event. Together, this provides a slip velocity of $1.0 \mathrm{~m} \mathrm{~s}^{-1}$ for $15 \mathrm{~cm}$ in $0.15 \mathrm{~s}$.

To assess the effect of such slip conditions on the SHV andesite, we performed a high-velocity rotary shear experiment using a normal stress (10 MPa) representative of approximately $500 \mathrm{~m}$ depth in the upper conduit. In this experiment two $25 \mathrm{~mm}$ diameter hollow cores ( $9.5 \mathrm{~mm}$ holes) were brought into contact and the axial stress was applied.
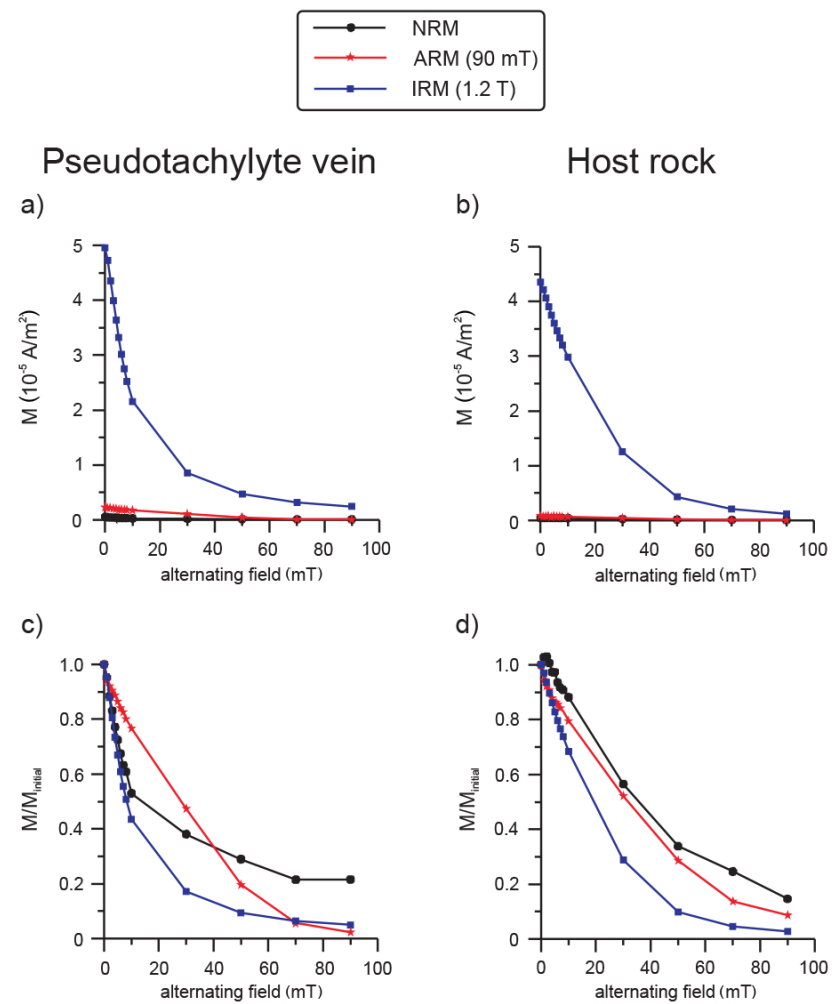

Fig. 8. Rock magnetic measurements. Alternating field demagnetisations of NRM, ARM and IRM of pseudotachylyte and host rock. Shown are first (a, b) magnetisation versus alternating field, then (c, d) normalised magnetisation (normalisation using initial magnetisation at $0 \mathrm{mT}$ alternating field) versus alternating field. NRM of the pseudotachylyte is analogue to an IRM while the NRM of the host rock is analogue to an ARM.

Next, one side was rotated at a velocity of $1.0 \mathrm{~m} \mathrm{~s}^{-1}$ as the simulated fault was recorded by optical and thermographic videos to track the temperature profile and observe melting (see Hirose and Shimamoto (2005) for more details of methodology; see supplementary video). When considering a magmatic temperature of $800^{\circ} \mathrm{C}$ in the conduit (Devine et al., 1998; Hale et al., 2007; Murphy et al., 2000; Barclay et al., 1998; Melnik and Sparks, 2002) at the onset of the process, these slip conditions are more than enough to force the andesite through the amphibole stability field at $855^{\circ} \mathrm{C}$ (Rutherford and Devine, 2003) and on into frictional melting above $950^{\circ} \mathrm{C}$ (Fig. 10a and supplementary video). At the onset of displacement the shear stress rapidly increases as isolated pockets of melt begin to form, shear resistance to slip is at its maximum immediately prior to a continuous melt layer forming on the slip surface (Fig. 10b). As this melt zone thickens resistance reduces and achieves a stable value of $\sim 3 \mathrm{MPa}$ as the melt is produced and expelled (shortening, Fig. 10b) at a constant rate. Once melt forms, the shear resistance is controlled by melt viscosity, and hence the behaviour may contrast significantly to the frictional behaviour 


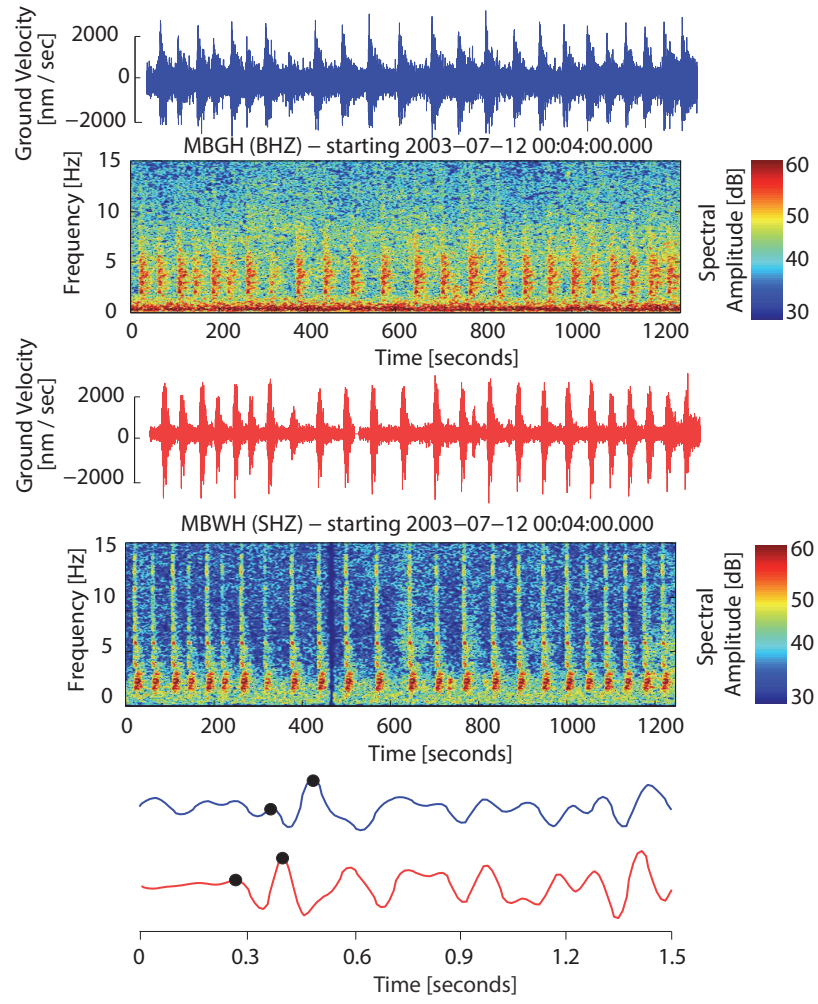

Fig. 9. Repetitive seismicity at Soufrière Hills volcano. Seismograms for $18 \mathrm{~min}$ of repeating earthquakes at stations MBGH and MBWH recorded on 12 July 2003 approximately $12 \mathrm{hr}$ before the largest dome collapse in SHV history. Bottom panel: The black dots highlight the width of a single $\mathrm{P}$-wave pulse from the seismograms above, which provide an estimate of source duration.

of rock-rock sliding or gouge-hosting shear zones (Spray, 2010; Magloughlin and Spray, 1992; Lin and Shimamoto, 1998).

\section{Discussion and conclusions}

This study documents evidence of frictional melting in ascending, conduit-dwelling magma. The presence of pseudotachylyte is verified using a multi-parametric approach that assesses its structural and mineralogical character as well as its distinct thermal and magnetic signatures.

The drastic contrast in mineralogical assemblage and petrographic textures between host rock and shear band suggest that it formed due to comminution and localised melting of the host rock during faulting and frictional slip of the viscous magma. The metastable melt was then able to crystallise slowly due to the high volcanic geotherm, forming the crystalline pseudotachylyte vein, with fine-grained, equant crystals (Figs. 2d, 5b, 6). This accounts for the lower porosity and permeability of the pseudotachylyte layers as compared to the cataclasite or the host rock (see Fig. 4) and indicates that

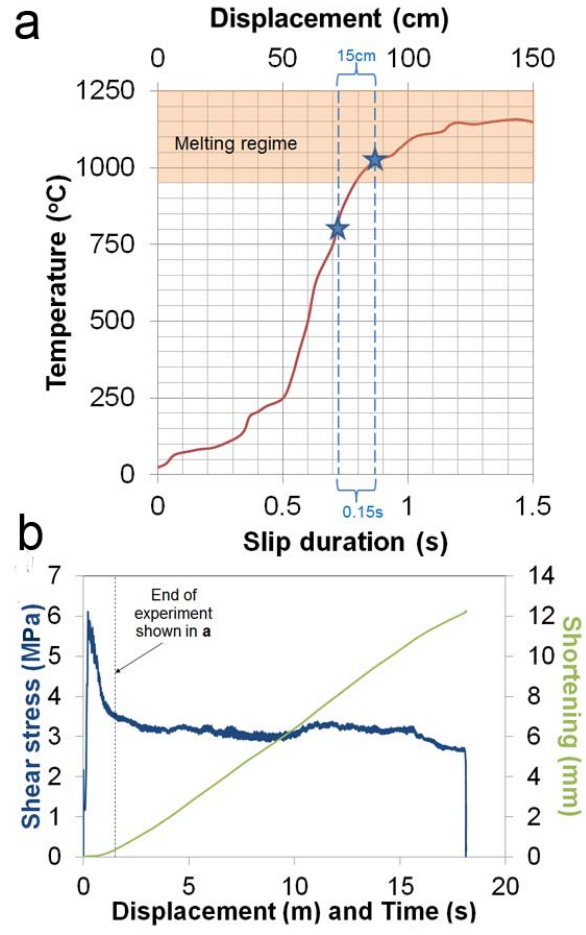

Fig. 10. Frictional melting of SHV andesite using a high velocity rotary shear apparatus. (a) Increasing temperature with time and slip distance at $10 \mathrm{MPa}$ normal load and $1.0 \mathrm{~m} \mathrm{~s}^{-1}$ slip velocity. Temperature was recorded using $\mathrm{H} 2640 \mathrm{NEC} \backslash$ Avio at a resolution of $90 \mu \mathrm{m} \times 90 \mu \mathrm{m}$ per pixel with no correction for melt cooling. Starting from room temperature melting is achieved in $0.75 \mathrm{~s}(75 \mathrm{~cm})$. The blue stars represent the change in temperature that results from a slip episode of $15 \mathrm{~cm}$ in $0.15 \mathrm{~s}$ (displacement parameters calculated from the seismic events at SHV in Fig. 9) from a starting magmatic temperature of $800^{\circ} \mathrm{C}$, where the magma temperature is increased by friction to $1025^{\circ} \mathrm{C}$ in that interval, with the onset of melting occurring at approximately $950^{\circ} \mathrm{C}$ (see also supplementary video). (b) Shear resistance (MPa) with slip duration and displacement during the experiment showing rapid increase in resistance as melting begins, followed by a peak as a full melt layer forms and attainment of steady state as melt supply rate and melt ejection (shortening) equilibrate.

when pseudotachylyte forms as part of a shear band this will alter the development of the permeable porous network. Indeed, the presence of chlorite (Fig. 6d), a distinct geochemical signature, and other evidence suggests that the shear zone was involved in degassing in the magma column (Plail et al., 2014).

The melting and recrystallisation of the magma lockedin a distinct thermal history, unravelled here using DSC. Contrasting melting temperatures of the pseudotachylyte versus the host rock, and the occurrence of different phase changes during heating and cooling of the sample subsets reveal their divergent petrogenesis, confirming the thermal anomaly. The disparate magnetic signature of the vein and 
host rock, resulting from high electric currents during faulting and frictional slip, serves to confirm the pseudotachylyte status. Indeed the demagnetisation experiments performed provide some of the clearest evidence to distinguish between pseudotachylyte and host rock (Ferré et al., 2005; Freund et al., 2007).

At Soufrière Hills the formation of the pseudotachylyte is considered to have been contemporaneous with repetitive LP seismicity, caused by stick-slip extrusion that persisted throughout the eruption. Finally, we tested this hypothesis by recreating the frictional melting process using a high velocity rotary shear apparatus and slip conditions relevant to the volcanic scenario; measured source duration of LP events, combined with calculations of slip distances provided the parameters required for the experiment. This highlighted that andesite magma, subjected to slip at $1 \mathrm{~m} \mathrm{~s}^{-1}$, can be forced to frictionally melt in $<0.15 \mathrm{~m}$ of slip, proving to be a viable response to seismogenic magma fracture. This may be a common occurrence; causing buoyant forces acting on the magma at depth to be superseded by frictional and viscosity controlled slip at the conduit margin. This indicates that frictional melting could have an important influence on the ongoing development of eruptions at dome-building volcanoes.

\section{Supplementary material related to this article is available online at http://www.solid-earth.net/5/199/ 2014/se-5-199-2014-supplement.zip.}

Acknowledgements. Thanks to A. Biggin and E. Hurst from the Geomagnetism Group at the University of Liverpool for performing the VFTB measurements. Thanks also to Alan R. Butcher (FEI) and Gavyn K. Rollinson (CSM, Exeter) for performing the QEMSCAN study and to S. Wiesmaier and D. Mueller for technical assistance. Y. Lavallee wishes to acknowledge the support of the Deutsche Forschungsgemeinschaft grant LA2191/3-1 as well as the ERC Starting Grant Strain Localisation in Magma (SLiM, \#306488). D. B. Dingwell wishes to acknowledge the support of a research professorship of the Bundesexzellenzinitiative (LMUexcellent), the EU funded FP7 activity 6.1 VUELCO consoritum and ERC Advanced Grant Explosive Volcanism in the Earth System (EVOKES, \#247076). A. Ferk and R. Leonhardt acknowledge funding by the Austrian Science foundation FWF (Grant P21221-N14).

Edited by: M. Heap

\section{References}

Barclay, J., Rutherford, M. J., Carroll, M. R., Murphy, M. D., Devine, J. D., Gardner, J., and Sparks, R. S. J.: Experimental phase equilibria constraints on pre-eruptive storage conditions of the Soufriere Hills magma, Geophys. Res. Lett., 25, 3437-3440, doi:10.1029/98GL00856, 1998.
Carn, S. A., Watts, R. B., Thompson, G., and Norton, G. E.: Anatomy of a lava dome collapse: The 20 march 2000 event at Soufrière Hills volcano, Montserrat, J. Volcanol. Geoth. Res., 131, 241-264, doi:10.1016/S0377-0273(03)00364-0, 2004.

Cashman, K. V., Thornber, C. R., and Pallister, J. S.: From dome to dust: Shallow crystallization and fragmentation of conduit magma during the 2004-2006 dome extrusion of Mount St. Helens, Washington, in: A volcano rekindled: A volcano rekindled: The renewed eruption of mount St. Helens, 2004-2006. Professionnal paper 1750., edited by: Sherrod, D. R., Scott, W. E., and Stauffer, P. H., U.S. Geological Survey, 387-413, 2008.

Castro, J. M., Cordonnier, B., Tuffen, H., Tobin, M. J., Puskar, L., Martin, M. C., and Bechtel, H. A.: The role of meltfracture degassing in defusing explosive rhyolite eruptions at volcán Chaitén, Earth Planet. Sci. Lett., 333-334, 63-69, doi:10.1016/j.eps1.2012.04.024, 2012.

Cordonnier, B., Caricchi, L., Pistone, M., Castro, J., Hess, K.-U., Gottschaller, S., Manga, M., Dingwell, D. B., and Burlini, L.: The viscous-brittle transition of crystal-bearing silicic melt: Direct observation of magma rupture and healing, Geology, 40, 611-614, doi:10.1130/g3914.1, 2012.

Costa, A., Wadge, G., and Melnik, O.: Cyclic extrusion of a lava dome based on a stick-slip mechanism, Earth Planet. Sci. Lett., 337-338, 39-46, doi:10.1016/j.eps1.2012.05.011, 2012.

Curewitz, D. and Karson, J. A.: Ultracataclasis, sintering, and frictional melting in pseudotachylytes from east Greenland, J. Struct. Geol., 21, doi:10.1016/S0191-8141(99)00119-4, 16931713, 1999.

De Angelis, S.: Seismic source displacement by coda wave interferometry at Soufrière Hills volcano, Montserrat, W.I., Nat. Hazards Earth Syst. Sci., 9, 1341-1347, doi:10.5194/nhess-9-1341-2009, 2009.

De Angelis, S. and Henton, S. M.: On the feasibility of magma fracture within volcanic conduits: Constraints from earthquake data and empirical modelling of magma viscosity, Geophys. Res. Lett., 38, L19310, doi:10.1029/2011g1049297, 2011.

Devine, J. D., Murphy, M. D., Rutherford, M. J., Barclay, J., Sparks, R. S. J., Carrol, M. R., Young, S. R., and Gardner, J. E.: Petrologic evidence for pre-erptive pressure-temperature conditions, and recent reheating, of andesitic magma erupting at the Soufrière Hills volcano, Montserrat, W.I, Geophys. Res. Lett., 25, doi:10.1029/98GL01330, 3669-3672, 1998.

Edmonds, M., and Herd, R. A.: A volcanic degassing event at the explosive-effusive transition, Geophys. Res. Lett., 34, L21310, doi:10.1029/2007GL031379, 2007.

Ferré, E. C., Zechmeister, M. S., Geissman, J. W., MathanaSekaran, N., and Kocak, K.: The origin of high magnetic remanence in fault pseudotachylites: Theoretical considerations and implication for coseismic electrical currents, Tectonophysics, 402, 125139, doi:10.1016/j.tecto.2005.01.008, 2005.

Freund, F., Salgueiro da Silva, M. A., Lau, B. W. S., Takeuchi, A., and Jones, H. H.: Electric currents along earthquake faults and the magnetization of pseudotachylite veins, Tectonophysics, 431, 131-141, doi:10.1016/j.tecto.2006.05.039, 2007.

Gottlieb, P., Wilkie, G., Sutherland, D., Ho-Tun, E., Suthers, S., Perera, K., Jenkins, B., Spencer, S., Butcher, A., and Rayner, J.: Using quantitative electron microscopy for process mineralogy applications, JOM, 24-25, 2000. 
Griffith, W. A., Mitchell, T. M., Renner, J., and Di Toro, G.: Coseismic damage and softening of fault rocks at seismic depths, Earth and Planetary Science Letters, 353, 219-230, doi:10.1016/j.epsl.2012.08.013, 2012.

Grunewald, U., Sparks, R. S. J., Kearns, S., and Komorowski, J. C.: Friction marks on blocks from pyroclastic flows at the Soufrière Hills volcano, Montserrat: Implications for flow mechanisms, Geology, 28, 827-830, doi:10.1130/00917613(2000) $28<827:$ fmobfp $>2.0 . c 0 ; 2,2000$.

Hale, A. J., Wadge, G., and Muhlhaus, H. B.: The influence of viscous and latent heating on crystal-rich magma flow in a conduit, Geophys. J. Int., 171, 1406-1429, doi:10.1111/j.1365246X.2007.03593.x, 2007.

Hale, A. J. and Wadge, G.: The transition from endogenous to exogenous growth of lava domes with the development of shear bands, J. Volcanol. Geoth. Res., 171, 237-257, doi:10.1016/j.jvolgeores.2007.12.016, 2008.

Harrington, R. M. and Brodsky, E. E.: Volcanic hybrid earthquakes that are brittle-failure events, Geophys. Res. Lett., 34, doi:10.1029/2006GL028714, 2007.

Harrington, R. M. and Brodsky, E. E.: Source duration scales with magnitude differently for earthquakes on the San Andreas fault and on secondary faults in Parkfield, California, Bull. Seismol. Soc. Am., 99, 2323-2334, doi:10.1785/0120080216, 2009.

Heap, M. J., Baud, P., Meredith, P. G., Vinciguerra, S., and Reuschlé, T.: The permeability and elastic moduli of tuff from Campi Flegrei, Italy: Implications for ground deformation modelling, Solid Earth, 5, 25-44, doi:10.5194/se-5-25-2014, 2014.

Herd, R. A., Edmonds, M., and Bass, V. A.: Catastrophic lava dome failure at Soufrière Hills volcano, Montserrat, 12-13 july 2003, J. Volcanol. Geoth. Res., 148, 234-252, doi:10.1016/j.jvolgeores.2005.05.003, 2005.

Hirose, T. and Shimamoto, T.: Slip-weakening distance of faults during frictional melting as inferred from experimental and natural pseudotachylytes, Bull. Seis. Soc. Am., 95, 1666-1673, doi:10.1785/0120040131, 2005.

Iverson, R. M., Dzurisin, D., Gardner, C. A., Gerlach, T. M., LaHusen, R. G., Lisowski, M., Major, J. J., Malone, S. D., Messerich, J. A., Moran, S. C., Pallister, J. S., Qamar, A. I., Schilling, S. P., and Vallance, J. W.: Dynamics of seismogenic volcanic extrusion at Mount St. Helens in 2004-05, Nature, 444, 439-443, doi:10.1038/nature05322, 2006.

Kendrick, J. E., Lavallée, Y., Ferk, A., Perugini, D., Leonhardt, R., and Dingwell, D. B.: Extreme frictional processes in the volcanic conduit of Mount St. Helens (USA) during the 2004-2008 eruption, J. Struct. Geol., 38, 61-76, doi:10.1016/j.jsg.2011.10.003, 2012.

Kendrick, J. E., Lavallée, Y., Hess, K.-U., Heap, M. J., Gaunt, H. E., Meredith, P. G., and Dingwell, D. B.: Tracking the permeable porous network during strain-dependent magmatic flow, J. Volcanol. Geoth. Res., doi:10.1016/j.jvolgeores.2013.05.012, 2013.

Kennedy, L. A., Russell, J. K., and Nelles, E.: Origins of Mount St. Helens cataclasites: Experimental insights, American Mineralogist, 94, 995-1004, doi:10.2138/am.2009.3129, 2009.

Kennedy, L. A. and Russell, J. K.: Cataclastic production of volcanic ash at Mount St. Helens, Physics and Chemistry of the Earth, Parts A/B/C, 45-46, 40-49, doi:10.1016/j.pce.2011.07.052, 2012.
Kim, J. W., Ree, J. H., Han, R., and Shimamoto, T.: Experimental evidence for the simultaneous formation of pseudotachylyte and mylonite in the brittle regime, Geology, 38, 1143-1146, doi:10.1130/g31593.1, 2010.

Kirkpatrick, J. D. and Rowe, C. D.: Disappearing ink: How pseudotachylytes are lost from the rock record, J. Struct. Geol., 52, 183-198, doi:10.1016/j.jsg.2013.03.003, 2013.

Laumonier, M., Arbaret, L., Burgisser, A., and Champallier, R.: Porosity redistribution enhanced by strain localization in crystalrich magmas, Geology, 39, 715-718, doi:10.1130/g31803.1, 2011.

Lavallée, Y., Meredith, P. G., Dingwell, D. B., Hess, K. U., Wassermann, J., Cordonnier, B., Gerik, A., and Kruhl, J. H.: Seismogenic lavas and explosive eruption forecasting, Nature, 453, 507510, doi:10.1038/nature06980, 2008.

Lavallée, Y., Benson, P., Hess, K.-U., Flaws, A., Schillinger, B., Meredith, P. G., and Dingwell, D. B.: Reconstructing magma failure and the permeable degassing network, Geology, 41, 515518, doi:10.1130/G33948.1, 2013.

Lensky, N. G., Sparks, R. S. J., Navon, O., and Lyakhovsky, V.: Cyclic activity at Soufrière Hills volcano, Montserrat: Degassing-induced pressurization and stick-slip extrusion, Geol. Soc. Lond. Spec. Publ., 307, 169-188, doi:10.1144/sp307.10, 2008.

Lin, A. and Shimamoto, T.: Selective melting processes as inferred from experimentally generated pseudotachylytes, J. Asian Earth Sci., 16, 533-545, doi:10.1016/s0743-9547(98)00040-3, 1998.

Lin, A. M.: Injection veins of crushing-originated pseudotachylyte and fault gouge formed during seismic faulting, Engineer. Geol., 43, 213-224, doi:10.1016/0013-7952(96)00062-2, 1996.

Luckett, R., Loughlin, S., De Angelis, S., and Ryan, G.: Volcanic seismicity at Montserrat, a comparison between the 2005 dome growth episode and earlier dome growth, J. Volcanol. Geoth Res., 177, 894-902, doi:10.1016/j.jvolgeores.2008.07.006, 2008.

Magloughlin, J. F. and Spray, J. G.: Frictional melting processes and products in geological materials, Geological society of america annual meeting, Science Direct, 141 pp., doi:10.1016/00401951(92)90307-R, 1992.

Melnik, O. E. and Sparks, R. S. J.: Dynamics of magma ascent and lava extrusion at the Soufrière Hills volcano, Montserrat, in: The eruption of the Soufrière Hills volcano, Montserrat from 1995 to 1999, edited by: Kokelaar, T. D. B., Geol. Soc. Lond., 153-172, 2002.

Murphy, M. D., Sparks, R. S. J., Barclay, J., Carroll, M. R., and Brewer, T. S.: Remobilization of andesite magma by intrusion of mafic magma at the Soufrière Hills volcano, Montserrat, West Indies, J. Petrol., 41, 21-42, doi:10.1093/petrology/41.1.21, 2000.

Neuberg, J., Baptie, B., Luckett, R., and Stewart, R.: Results from the broadband seismic network on Montserrat, Geophys. Res. Lett., 25, 3661-3664, doi:10.1029/98GL01441, 1998.

Neuberg, J., Tuffen, H., Collier, L., Green, D., Powell, T., and Dingwell, D.: The trigger mechanism of low-frequency earthquakes on Montserrat, J. Volcanol. Geoth. Res., 153, 37-50, doi:10.1016/j.jvolgeores.2005.08.008, 2006.

Okumura, S., Nakamura, M., Nakano, T., Uesugi, K., and Tsuchiyama, A.: Shear deformation experiments on vesicular rhyolite: Implications for brittle fracturing, degassing, and com- 
paction of magmas in volcanic conduits, J. Geophys. Res.: Solid Earth, 115, n/a-n/a, doi:10.1029/2009JB006904, 2010.

Pirrie, D., Butcher, A. R., Power, M. R., Gottlieb, P., and Miller, G. L.: Rapid quantitative mineral and phase analysis using automated scanning electron microscopy (qemscan); potential applications in forensic geoscience, Forensic geoscience, principles, techniques and applications, edited by: Pye, K., Croft, D. J., Geol. Soc. Spec. Publ., London, 2004.

Plail, M., Edmonds, M., Barclay, J., Humphreys, M. C. S., and Herd, R.: Geochemical evidence for relict degassing pathways preserved in andesite, Earth Planet. Sci. Lett., 386, 21-33, doi:10.1016/j.eps1.2013.10.044, 2014.

Rowe, C. A., Thurber, C. H., and White, R. A.: Dome growth behavior at Soufrière Hills volcano, Montserrat, revealed by relocation of volcanic event swarms, 1995-1996, J. Volcanol. Geoth. Res., 134, 199-221, doi:10.1016/j.jvolgeores.2004.01.008, 2004.

Rowe, C. D., Moore, J. C., Meneghini, F., and McKeirnan, A. W.: Large-scale pseudotachylytes and fluidized cataclasites from an ancient subduction thrust fault, Geology, 33, 937-940, doi:10.1130/g21856.1, 2005.

Rutherford, M. J. and Devine, J. D.: Magmatic conditions and magma ascent as indicated by hornblende phase equilibria and reactions in the 1995-2002 Soufrière Hills magma, J. Petrol., 44, 1433-1453, doi:10.1093/petrology/44.8.1433, 2003.

Sibson, R. H.: Generation of pseudotachylyte by ancient seismic faulting, Royal Astronomical Society of London Journal, 43, doi:10.1111/j.1365-246X.1975.tb06195.x, 1975.

Sibson, R. H.: Fault rocks and fault mechanisms, J. Geolog. Soc., 133, doi:10.1144/gsjgs.133.3.0191, 1977.

Sosman, R. B.: The phases of silica, Rutgers University Press, New Brunswick, N. J., 389 pp., 1965.

Spray, J. G.: Frictional melting processes in planetary materials: From hypervelocity impact to earthquakes, Annu. Rev. Earth Planet. Sci., 38, 221-254, doi:10.1146/annurev.earth.031208.100045, 2010.
Swanson, M. T.: Fault structure, wear mechanisms and rupture processes in pseudotachylyte generation, Tectonophysics, 204, 223242, doi:10.1016/0040-1951(92)90309-T, 1992.

Tuffen, H. and Dingwell, D.: Fault textures in volcanic conduits: Evidence for seismic trigger mechanisms during silicic eruptions, Bull. Volcanol., 67, 370-387, doi:10.1007/s00445-0040383-5, 2005.

Voight, B., Sparks, R. S., Miller, A. D., Stewart, R. C., Hoblitt, R. P., Clarke, A., Ewart, J., Aspinall, W. P., Baptie, B., Calder, E. S., Cole, P., Druitt, T. H., Hartford, C., Herd, R. A., Jackson, P., Lejeune, A. M., Lockhart, A. B., Loughlin, S. C., Luckett, R., Lynch, L., Norton, G. E., Robertson, R., Watson, I. M., Watts, R., and Young, S. R.: Magma flow instability and cyclic activity at Soufrière Hills volcano, Montserrat, British West Indies, Science, 283, 1138-1142, 1138-1142, doi:10.1126/science.283.5405.1138, 1999.

Voight, B. and Elsworth, D.: Instability and collapse of hazardous gas-pressurized lava domes, Geophys. Res. Lett., 27, 1-4, doi:10.1029/1999GL008389, 2000.

Watts, R. B., Herd, R. A., Sparks, R. S., and Young, S. R.: Growth patterns and emplacement of the andesitic lava dome at soufriere hills volcano, in: The eruption of Soufrière Hills volcano, Montserrat, from 1995 to 1999, edited by: Druitt, T. H., and Kokelaar, B. P., Geol. Soc. Lond. Memoirs, 115-152, 2002.

Zellmer, G. F., Hawkesworth, C. J., Sparks, R. S. J., Thomas, L. E., Harford, C. L., Brewer, T. S., and Loughlin, S. C.: Geochemical evolution of the Soufrière Hills volcano, Montserrat, Lesser Antilles volcanic arc, J. Petrol., 44, 1349-1374, doi:10.1093/petrology/44.8.1349, 2003. 


\section{Appendix A}

\section{Materials and methods}

\section{A1 Thermal measurements}

Thermogravimetric measurements (TG) and low sensitivity scanning calorimetry (LS-DSC) were carried out using a Netzsch STA 449 C simultaneous thermal analysis equipment. Small chips of about $50 \mathrm{mg}$ were heated in a Pt crucible (with lid) with a heating rate of $10 \mathrm{~K} \mathrm{~min}^{-1}$ up to $1500^{\circ} \mathrm{C}$ in air. High sensitivity scanning calorimetry measurements (HS-DSC) were carried out using a Netzsch DSC 404 C. Small chips of about $25 \mathrm{mg}$ were heated in a Pt crucible (with lid) with a heating rate of $10^{\circ} \mathrm{C} \mathrm{min}^{-1}$ up to $1000^{\circ} \mathrm{C}$ in air, cooled with $10 \mathrm{~K} \mathrm{~min}^{-1}$ to $100^{\circ} \mathrm{C}$ and then reheated to $1000^{\circ} \mathrm{C}$.

\section{A2 Magnetic measurements}

Rock magnetic measurements were made on the variable field translation balance by Petersen Instruments at the University of Liverpool. Remanence carriers defined as low coercive materials (saturation of an isothermal remanence, IRM, below $200 \mathrm{mT}$ ). A second experiment used alternating field demagnetisation of different remanent magnetisations. This experiment was run in a magnetically shielded room at LMU Munich, using the SushiBar - an automated system for palaeomagnetic investigations (Wack and Gilder, 2012). First, the natural remanence NRM was measured and then demagnetised using 14 steps of increasingly higher alternating fields. Then an anhysteretic remanent magnetisation (ARM) was implied. An ARM is produced by the combination of a slowly decaying alternating field and a steady unidirectional field. For the ARM a maximum field of $90 \mathrm{mT}$ was applied. This ARM was measured and then demagnetised in the same manner as the NRM. Finally an IRM using a 1.2 T magnetic field was implied, measured and again stepwise demagnetised.

\section{A3 Scanning electron microprobe}

Uncovered thin sections of each sample were carbon coated for analysis in a CAMECA SX100 scanning electron microprobe. Backscatter electron (BSE) images (Fig. 5) highlight grain-size and density differences between the pseudotachylyte, cataclasite and host rock. Specific minerals within the samples were analysed using wavelength dispersive analysis (WDA) to verify the mineralogy identified by optical analysis.

\section{A4 QEMSCAN}

QEMSCAN (Quantitative Evaluation of Minerals by SCANning electron microscopy) analysis was completed at the Camborne School of Mines laboratory facility, University of Exeter, UK. The uncovered, polished thin section was carbon coated and then scanned using the Fieldscan measurement mode, which in this case was programmed to collect an X-ray analysis every $10 \mu \mathrm{m}$ across the sample surface in a grid (for further details see Gottlieb et al., 2000; Pirrie et al., 2004). System settings were $25 \mathrm{kV}$ with a $5 \mathrm{nA}$ beam, and $\mathrm{X}$ rays were acquired at 1000 total $\mathrm{X}$-ray counts per spectrum. Resulting data (approximately 5 million data points) were processed using iDiscover software to produce customised mineral data appropriate for the sample type. This involved modifying the SIP (database) to be accurate for the sample type, assisted by the geological context of the sample. Data output included quantitative modal mineralogy, a BSE map, a full false colour mineral map and individual mineral maps for each mineral type.

\section{A5 Tomography}

3-D high-resolution tomography images were acquired through v/tome/x s 240 micro-CT scanner from GE phoenix using a high-power X-ray tube and a drx-250 rt (real time) detector system (experimental conditions: pixel/voxel size: $20.0 \mu \mathrm{m}, 1000$ images for $360^{\circ}$ (average of three single images, one image skipped), exposure time of $1 \mathrm{~s}$, voltage of $80 \mathrm{kV}$ and current of $250 \mu \mathrm{A}$ ).

\section{A6 Porosity and permeability}

Porosity was measured on $5 \mathrm{~mm}$ by $5 \mathrm{~mm}$ cores using an AccuPyc 1330 helium pycnometer from Micromeritics. Water permeability was measured in a servo-controlled steadystate-flow permeameter at effective pressures of 5-50 MPa (Fig. 6). The effective pressure is taken as the confining pressure minus the pore fluid pressure (this assumes that the poroelastic constant $\alpha$ is equal to one, see Guéguen and Palciauskas, 1994). Upstream and downstream pore fluid pressures were 9.5 and $10.5 \mathrm{MPa}$, respectively (a $1 \mathrm{MPa}$ pressure differential across the sample). Water permeability ( $\kappa$ water) was calculated during steady-state flow using Darcy's law:

$Q / A=\kappa_{\text {water }} / \eta L\left(P_{\text {up }}-P_{\text {down }}\right)$

where $Q$ is the volume of fluid measured per unit time, $A$ is the cross-sectional area of the sample, $\eta$ is the viscosity of the pore fluid, and L is the length of the sample. 